\title{
Social Issues in Supply Chain Sustainability - Focus Areas for Energy and Manufacturing sectors in India and USA
}

\author{
By Prashant Unnikrishnan Nair ${ }^{1}$, Parvathy Thankamony ${ }^{2}$
}

\begin{abstract}
The paper is a capsule to understand various social issues in supply chain, the social sustainability practices and strategies used for mitigation. Data was collected through questionnaire survey and systematic literature review of the supply chain social sustainability papers, published in peer-reviewed journals within the time frame of January 2000 to October 2020. Findings from this study show that social aspects are less researched and practiced compared to economic and environmental dimensions of sustainability. Research is still at an infancy stage in the emerging economies with very few social sustainability-centered studies focusing on practices and metrics to measure the impact of these practices. The paper identifies 26 social issues for social sustainability in supply chain for two different economies and does a comparative study. Scope of the paper is limited to Manufacturing and Energy sectors in the USA and in India to seek a possible contrasting or adhering perspective to the issues. Results and discussion pertain to the chosen sectors and geographies and provide key insight on the perspectives in the region with a conclusion on further research and mitigation methods through research and implementation of corporate practices that can help mitigate systemic social issues.
\end{abstract}

Keywords: Social issue, Social sustainability, Supply chain, Strategy, Practice

\section{Introduction}

Supply chain, in its vast scope, covers all aspects, including firms, manpower, functions, data and other resources and processes involved in the acquisition of raw materials to the delivery of end products to customers. Given the vitality of it, a supply chain should be durable or "sustainable". Brundtland (1987) defined sustainable growth as the "development that meets the needs of the present without compromising the ability of future generations". Another popular definition explains supply chain sustainability as the consistent, strategic and planned integration and realization of economic, social and environmental goals of partner firms, in order to increase the long-term economic effectiveness of a supply chain through the structured coordination of pivot intercorporate processes (Olorunniwo \& Li, 2010).

There are 3 building blocks of sustainability - economic, environmental and social known en masse as the "triple bottom line" (Elkington, 1997). In a sustainable SCM, the triple bottom line goals are central to the management of data, funds and material flows and collaboration among the supply chain partners, according to Seuring and Müller (2008). Economic and environmental aspects are studied and implemented widely across industries, the social element is often neglected, owing to the misconceptions regarding 
high cost, time and other risks of implementation.

This paper provides a study of social issues in supply chain management through a questionnaire survey and systematic literature review. The initial section of this paper explains the methodology used for the study, followed by section three describing social issues in supply chain. Section four of the paper provides results of the survey and discussion of the analysis. The paper concludes with findings and discrepancies in supply chain social sustainability studies, thereby opening a way for future researchers.

\section{Methodology}

\subsection{A Systematic Literature Review (SLR):}

SLR is used for the purpose of this paper. The problem statement for this study was: "Identify the social issues in supply chain and the social sustainability practices the SC partners implement to mitigate them".

For the purposes of this paper "sustainable supply chain","sustainability in supply chain","socially sustainable supply chain","social sustainability in supply chain", "sustainable supply chain management", "supply chain" AND "social issues", "supply chain" AND "sustainability", "supply chain" AND "social sustainability"and other key words were utilized through Google search, Scopus and other such search engines.

Initial search resulted in 2000 papers, which comprised of the topics social issues, economic, environmental and social sustainability. It was therefore mandated to refine the search for further relevance, and through filtering and refinement 82 papers were finalized with subject relevant to the paper of this 30 served as references pertinent to the purposes of this paper. Figure 1 demonstrates the papers reviewed and the years in which they were submitted.

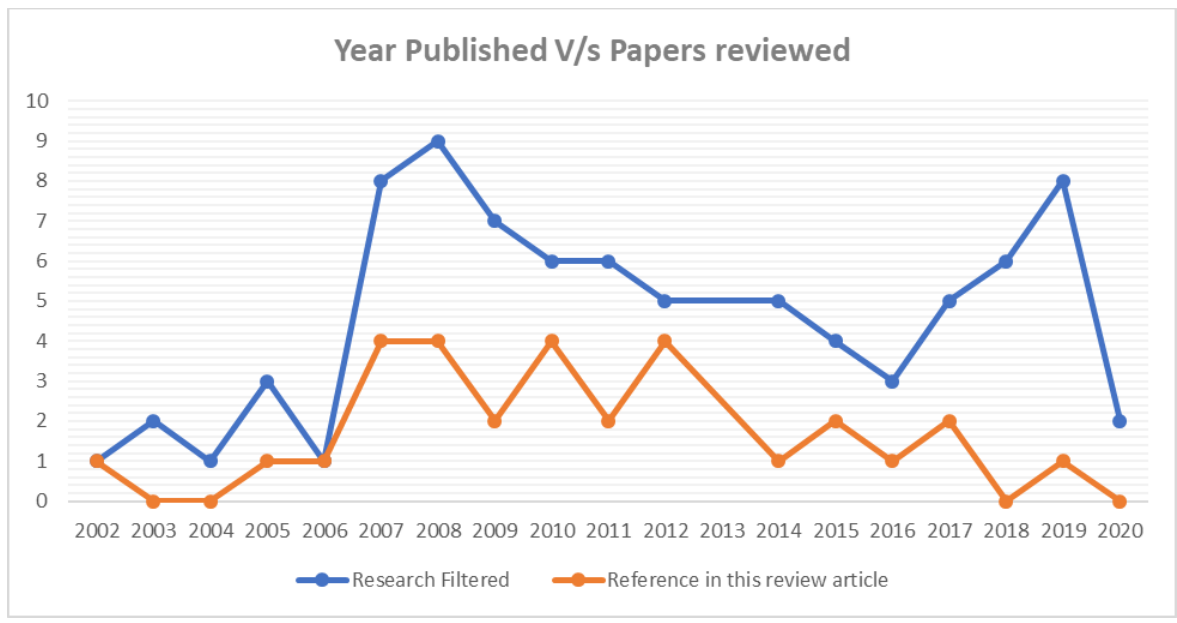

Figure 1: Papers reviewed Vs. Year published

\subsection{Questionnaire Survey:}

A questionnaire survey facilitated the method to understand the relevance of social issues in Indian and the US manufacturing and energy sectors. Data gathered 
through systematic literature review were used as key question points to access the industrial sector's significance. A survey was conducted to obtain a corporate perspective on various social issues. A sample size of 800 people for each geography and sector was initially targeted in consultation with four supply chain professionals with expertise of more than five years in the energy and manufacturing sectors. The consultancy ensured the relevancy of questions selected. As part of the brainstorming effort, seven different types of survey: Interview, Focus groups, Panel sampling, Telephone survey, Mail-in survey, Kiosk survey at business fairs, and online surveys, based on their different platforms was discussed along with incentivized and non-incentivized methods to obtain valuable data.

Further, "boon and bane", for data quality was determined to be critical. While the incentivized survey would bring results more quickly, it is important to ensure that people take such surveys with a genuine interest in the subject compared to those who would participate with the final goal of achieving the incentive. (Shamon and Berning, 2020).

Since the select group needed for the survey is educated and working, an online survey was determined to facilitate better results than the other methods. A telephonic introduction to the survey was selected as the method to attenuate efforts by ensuring that the surveyors fully understood the goal before they took the survey.

The format of the questions selected was according to the Havard University Program Survey Research to ensure primary, regency, randomizing effect (Chase, 2007). As social issues always carry an emotional element, it is vital that the questions are not monotonous. Changes in the question formats through the survey would therefore aid in ensuring that even the best survey participants are only drawn to the relevancy associated with the question compared to choosing answers based on their established emotional aspects in the previous question. (Vrinda Singh, 2019). One method of addressing it was the use of varied formats in the survey, challenging the surveyor on the same problems with varied relevancy on the firm and employee perspectives. It was also determined that changes in selection choices would elevate relevance and improve the engagement negating any emotional continuity. (Babbie,2010). Further, the Havard business review article on Workplace survey (Palmer Morrel-Samuels,2002) highlights, "One of the bestdocumented response biases is the tendency of respondents to agree with questions, a tendency that becomes more pronounced as work progresses through a survey."

As part of the survey response, the questionnaire was distributed through web and social media platforms. Over 12 months, an average of 358 responses from each sector and geography was obtained, as 362 Indian-energy, 359 Indian-manufacturing, 339 US-energy, and 372 US-manufacturing participants and determined as a substantial data sample set for the exercise. The survey is provided as a supplementary document for reference.

\section{Social Issues in Supply Chain (SC):}

Social Issues in any supply chain system ranges from child labor and wages to gender/race and community unemployment conditions. Of the many issues, Table 1 identifies those of the highest impact reviews, and each is briefly described. 
Table 1: List of social issues in SC

\begin{tabular}{|c|c|c|}
\hline Index & Social issues & Reference \\
\hline$A$ & Child labor & Nadvi, 2008; Kolk and Van Tuldere, 2002 \\
\hline$B$ & Consumer boycotts & Zadek, 2005; Klassen and Vereecke, 2012 \\
\hline$C$ & Employee rights & Björklund, 2010; Markley \& Davis, 2007; Ansett, 2007 \\
\hline $\bar{D}$ & Employment Discrimination & Roscigno, 2019 \\
\hline E & Ethics & Morais, 2017; Ellis \& Higgins, 2006; Kolk and Van Tuldere, 2002 \\
\hline F & Fair trade and transparency & Olorunniwo \& Li, 2010; Peters et al., 2011 \\
\hline G & Gender & Morais, 2017; Mani et al., 2015; Yawar and Seuring, 2017 \\
\hline$H$ & Health, safety and wellbeing & $\begin{array}{l}\text { Mani et al., 2015; Markley \& Davis, 2007; Morais, 2017; Yawar and } \\
\text { Seuring, 2017; Closs et al., 2011; Pullman et al., 2009 }\end{array}$ \\
\hline$I$ & Housing & Mani et al., 2015; Read et al., 2012 \\
\hline$J$ & Human rights violation & $\begin{array}{l}\text { Yawar and Seuring, 2017; Klassen and Vereecke, 2012; Mani et al., } \\
\text { 2015; Morais, } 2017\end{array}$ \\
\hline K & Labor conditions & $\begin{array}{l}\text { Klassen and Vereecke, 2012; Yawar and Seuring, 2017; Ageron et al., } \\
\text { 2012; Leire and Mont, 2009; Smith, 2007; Matos \& Hall, } 2007\end{array}$ \\
\hline$L$ & $\begin{array}{l}\text { Local community } \\
\text { empowerment }\end{array}$ & Simões, 2014; Morais, 2017 \\
\hline$M$ & Minority development & Morais, 2017; Yawar and Seuring, 2017 \\
\hline$N$ & $\begin{array}{l}\text { Neglected population } \\
\text { inclusion }\end{array}$ & Yawar and Seuring, 2017; Hall and Matos , 2010 \\
\hline$O$ & Philanthropic activities & Mani et al., 2016; Morais, 2017 \\
\hline$P$ & Population change & Hutchins and Sutherland, 2008; Ni et al., 2010 \\
\hline Q & Poverty reduction & Kortelainen, 2008; Yawar and Seuring, 2017 \\
\hline$R$ & Product responsibility & Morais, 2017 \\
\hline$S$ & Sanitation & Mani et al., 2016 \\
\hline$T$ & Supplier labor practices & Klassen and Vereecke, 2012 \\
\hline$U$ & Training \& Education & $\begin{array}{l}\text { Mani et al., 2015; Kumar and Rahman, 2015; Klassen and Vereecke, } \\
\text { 2012; Yawar and Seuring, } 2017\end{array}$ \\
\hline$V$ & Unemployment & Mani et al., 2015 \\
\hline$W$ & Unexpected negative events & Kleindorfer and Saad, 2005; Klassen and Vereecke, 2012 \\
\hline$X$ & Wages & $\begin{array}{l}\text { Mani et al., 2015; Kumar and Rahman, 2015; Yawar and Seuring, 2017; } \\
\text { Ashby et al., } 2012\end{array}$ \\
\hline $\bar{Y}$ & Women specific issues & $\begin{array}{l}\text { Mani et al., 2015; Kumar and Rahman, 2015; Yawar and Seuring, 2017; } \\
\text { Matos \& Hall, } 2007\end{array}$ \\
\hline$Z$ & Work-life balance & $\begin{array}{l}\text { Kumar and Rahman, 2015; Closs et al., 2011; Closs et al., 2011; } \\
\text { Markley \& Davis, } 2007\end{array}$ \\
\hline
\end{tabular}

Survey questions identified for target social issues are presented below in Table 2. Training and Development was intentionally removed from the survey in agreement with experts that this is a shortcoming globally across all sectors and geographies and needs attention regardless of survey results.

Table 2: queries pertaining to the issues.

\begin{tabular}{|l|l|}
\hline Survey Question & Pertaining Social Issues \\
\hline $\begin{array}{l}\text { Your organization actively considers Child labor as a } \\
\text { key social Issue (Agreed)? }\end{array}$ & Child labor, Human rights violation \\
\hline $\begin{array}{l}\text { Is local community empowerment given priority by your } \\
\text { organization? }\end{array}$ & Local community empowerment \\
\hline Minority development is key to the Corporation & Minority development \\
\hline $\begin{array}{l}\text { "Marginalized Population" exclusion is considered a } \\
\text { social issue for Supply Chains }\end{array}$ & Neglected population inclusion \\
\hline
\end{tabular}




\begin{tabular}{|c|c|}
\hline Survey Question & Pertaining Social Issues \\
\hline $\begin{array}{l}\text { My firm addresses unemployment issues around } \\
\text { communities to actively provide job opportunities? }\end{array}$ & Unemployment, Population change \\
\hline $\begin{array}{l}\text { You (not firm) believe employee rights are a key social } \\
\text { issue }\end{array}$ & Employee rights \\
\hline $\begin{array}{l}\text { Firm (not You) believes employee rights are a key } \\
\text { social issue }\end{array}$ & Employee rights, Human rights violation, Labor conditions \\
\hline $\begin{array}{l}\text { Corporate Ethics policy exists, and you know where to } \\
\text { find it }\end{array}$ & Ethics \\
\hline In my firm, trade is done in a fair manner. & Fair trade and transparency, Product responsibility \\
\hline $\begin{array}{l}\text { Does your Organization think poverty is an important } \\
\text { social issue that it can help reduce? }\end{array}$ & Poverty reduction, Population change \\
\hline $\begin{array}{l}\text { Your organization considers employee discrimination } \\
\text { (including Gender/Sexual orientation) as an } \\
\text { important issue }\end{array}$ & Gender, Employment Discrimination \\
\hline $\begin{array}{l}\text { Are women specific issues given importance in your } \\
\text { organization? }\end{array}$ & Women specific issues, Health, safety and wellbeing \\
\hline $\begin{array}{l}\text { Is employee work-life balance given attention by the } \\
\text { organization }\end{array}$ & Work-life balance, Labor conditions, Supplier labor practices \\
\hline $\begin{array}{l}\text { Do you think wage or salary is a social issue that your } \\
\text { organization should give more importance to? }\end{array}$ & Wages \\
\hline $\begin{array}{l}\text { Do you think your organization is prepared to face } \\
\text { unexpected negative events like earthquakes, } \\
\text { burricanes, pandemics etc.? }\end{array}$ & Unexpected negative events, Population change \\
\hline $\begin{array}{l}\text { Do you (not organization) think HOUSING and } \\
\text { SANITATION are social issues that the } \\
\text { organizations should help resolve in their communities? }\end{array}$ & Sanitation, Health, Safety and wellbeing, Labor conditions \\
\hline $\begin{array}{l}\text { Does your organization engage in voluntary } \\
\text { philanthropic initiatives and activities? }\end{array}$ & Philanthropic activities \\
\hline
\end{tabular}

\section{Results and Discussion}

A: According to a UNICEF study, worldwide, about 1 in 10 children (approximately 152 million) are exposed to child labor, and nearly $50 \%$ of them are subjected to hazardous work. Regulatory tools like codes of conduct and vendor agreements with clauses for minimum age requirement of permanent and contract staff help alleviate this issue to some extent (Kolk and Van Tuldere, 2002). Figure 2 provides a clear insight that developed sectors and regions clearly consider this a social issue. Many manufacturing entities in developed countries continue to use child labor despite government regulations prohibiting the same. The fact is depicted clearly in the Indian Manufacturing sector that is mostly privately owned and has a very low confidence on how firms address the issue.

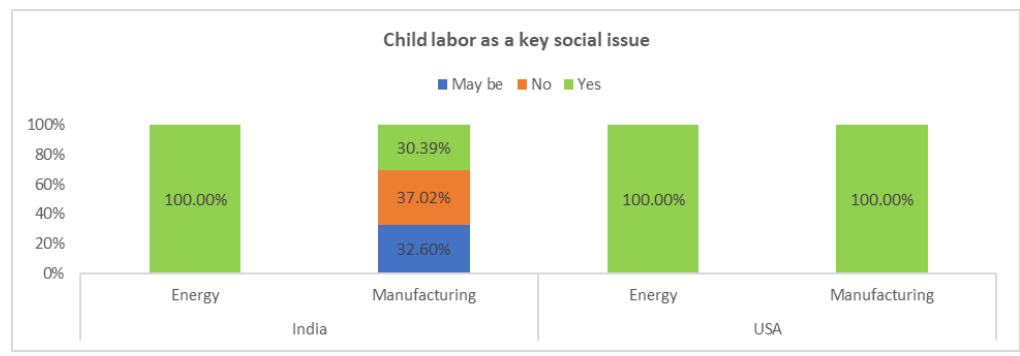

Figure 2: Child labor. 
B: Consumer boycotts is a persisting issue that gains media attention. In demand and supply networks, the reputation of partners is chain linked to each other. A supplier's lack of social responsibility impacts the reputation of their client firms and repercussions could lead to consumer boycotts (Zadek, 2005). Figure 2,3 5, 6, 10 and 17 responses influence the consumer boycott behavior.

C: According to Björklund (2010), if firms start taking labor/employee rights-focused, socially responsible supply chain decisions, in scenarios like vendor selection, the understanding of the importance of labor rights can be improved and soon persistent issue that linger in spite of legal challenges can be tackled. Figure 3 and 4 demonstrates that while most employees strongly agree on the importance of this as a social issue, their confidence on engagement from the firm is rather limited. In most cases employees perceive their firms to not consider it a major issue in sharp and striking contrast to their own perception.

\begin{tabular}{|c|c|c|c|c|c|c|}
\hline Perspective & $\begin{array}{l}\text { Not an issue in my } \\
\text { Opinion } \\
\text { (1) }\end{array}$ & (2) & (3) & (4) & \begin{tabular}{|c|} 
Without a Doubt - \\
Employee Rights are a key \\
issue to Social \\
sustainability \\
(5)
\end{tabular} & $\begin{array}{c}\% \text { of Survey } \\
\text { selections }\end{array}$ \\
\hline \multicolumn{7}{|r|}{$11.00 \%$} \\
\hline & & & & & $\Sigma$ & $89.00 \%$ \\
\hline \multicolumn{7}{|l|}{ Manufacturing-India } \\
\hline \multicolumn{7}{|l|}{ Energy-USA } \\
\hline \multirow{2}{*}{ Manufacturing-USA } & $z$ & & 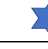 & & $\sqrt{3}$ & $2.10 \%$ \\
\hline & $\Sigma$ & & & & $\sum$ & $97.90 \%$ \\
\hline
\end{tabular}

Figure 3: Employee rights (employee perspective).

\begin{tabular}{|c|c|c|c|c|c|c|}
\hline Perspective & $\begin{array}{l}\text { Not an issue in my } \\
\text { Opinion } \\
\text { (1) }\end{array}$ & (2) & (3) & (4) & \begin{tabular}{|c|} 
Without a Doubt - \\
Employee Rights are a Key \\
issue to Social \\
sustainability \\
(5)
\end{tabular} & $\begin{array}{l}\text { Average } \\
\text { Rating }\end{array}$ \\
\hline Energy-India & $\sum$ & $\sqrt{3}$ & $\sqrt{3}$ & $\sum$ & $\sum \gamma$ & 1.87 \\
\hline Manufacturing-India & $\sum \sqrt{3}$ & $\sum \sqrt{3}$ & $\sum \sqrt{3}$ & $\sum \gamma$ & $\sum \sqrt{3}$ & 1.45 \\
\hline Energy-USA & $\sum \sqrt{3}$ & $\sum \sqrt{3}$ & $\sum 3$ & $\sum \sqrt{3}$ & $\sum 3$ & 3.07 \\
\hline Manufacturing-USA & $\sum^{*}$ & $\sum \sqrt{3}$ & $\sum \xi$ & $\sum \sqrt{2}$ & $\sum \sqrt{3}$ & 2.07 \\
\hline
\end{tabular}

Figure 4: Employee rights (firm's perspective).

D: According to the U.S Equal Employment Opportunity Commission, employee discrimination entails unfair treatment, harassment, declination of a reasonable workplace shift, inappropriate questioning/ disclosure and reprisal at the workplace. Very limited studies have been conducted on this aspect. According to Roscigno (2019), status, occupational position and workplace relations are the main drivers of this. Figure 7 captures the low confidence on this social aspect to be seamlessly addressed, however, US engagement shows a stronger Yes in comparison to Indian sectors where some form of engagement from management is essential to bring attention on issues.

E: Ethics has always been a prominent social issue, irrespective of the industry. Mani et al. (2016) have interpreted it as one of the most common and important social issues in their 
study. According to Morais (2017), a lack of ethics in businesses and the running of organizations driven by profits can be noticed in both developed and emerging countries; and can be reduced by codes of conduct and internal governance activities in the firms. Indian Manufacturing sector largely shows a gap, given there is a $\%$ of people that either didn't know the ethics policy exists in their organization or believe that it is not followed. This is an alarming find, given almost no surveyor chose yes it exists. The authors feel the responses could have been biased and reflects a take as a general subject compared to their independent firms, as several manufacturing firms in India do have published ethics policy and standard.

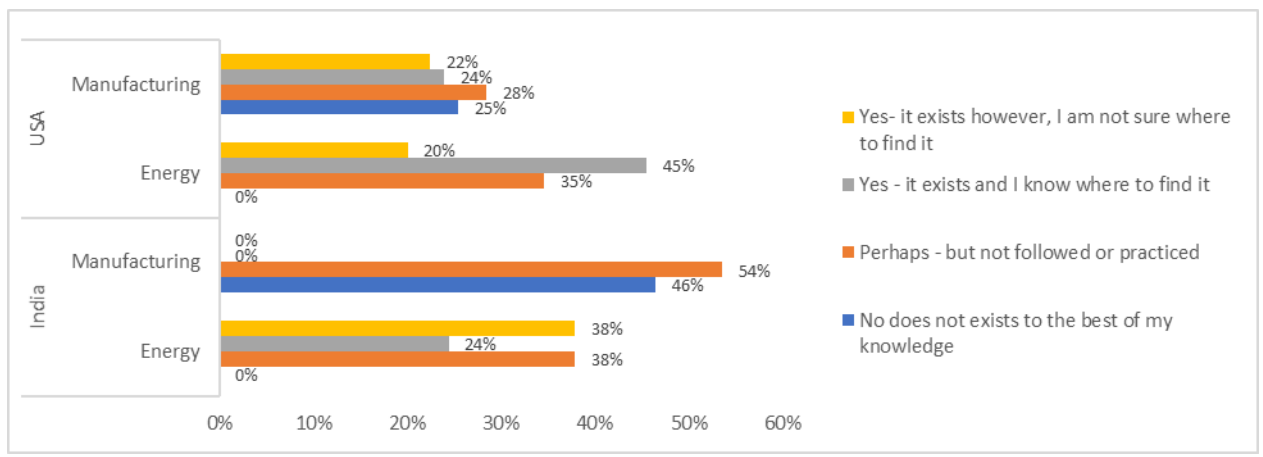

Figure 5: Corporate Ethics policy.

F: Information technology adaptation, collaboration and other supply chain management initiatives help in creating the transparency and fair-trade opportunities, thus establishing long term supply chain partnerships and trust among the partners (Olorunniwo \& Li, 2010). Figure 6 demonstrates that there is a stronger confidence on the customer side in comparison to the supplier side, while most results in the US seem to have a larger confidence on both the supplier and the customer but is not devoid of gaps either.

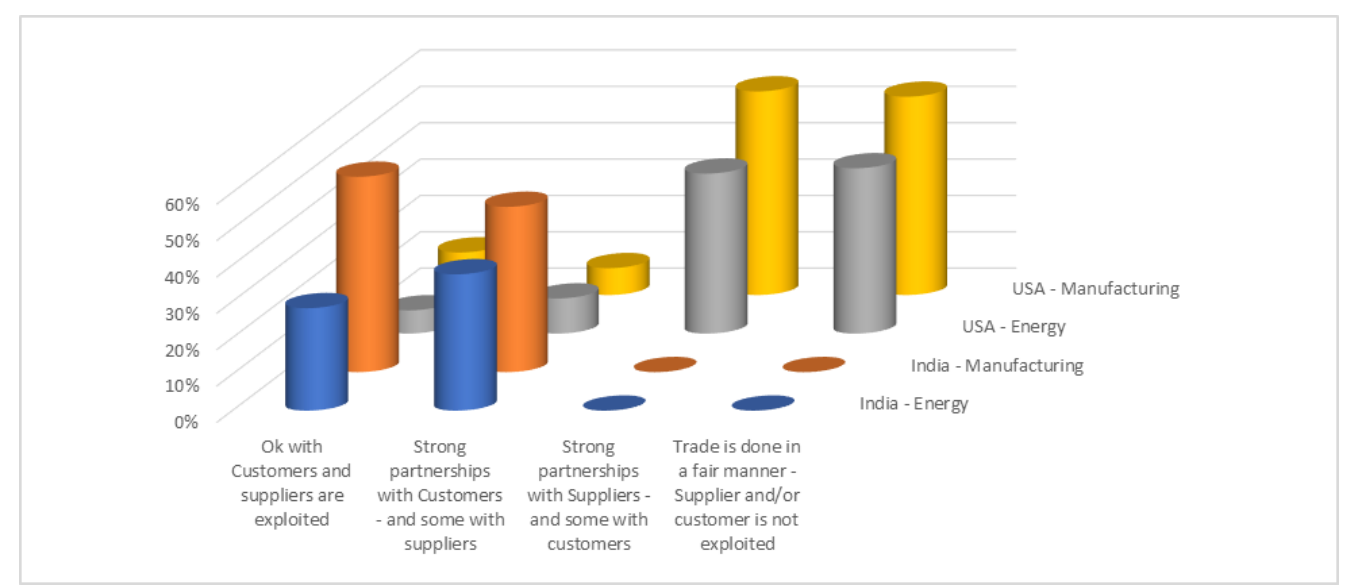

Figure 6: Fair trade. 
G: Gender, which, for the purposes of this paper, includes both gender non-diversity and discrimination (Yawar and Seuring, 2017; Mani et al., 2015) have continued to remain an unsolved bias. Supply chain organizations should create awareness about this and should promote activities, policies and disciplines to promote the equal treatment and rights of all genders at their and the SCM partner's workplace (Morais, 2017). Subsequently, increasing the female to male ratio at the workplace, and policy to promote diversity in promotions should also be a priority of the firms, to improve the gender diversity (Mani et al., 2015). Figure 7 demonstrates the vast improvement needed to address the social issue. Notice how both sectors in India highlight the lack of continuous monitoring and how lack of efforts or sidelining of issue continue to persist across sectors and geographies.

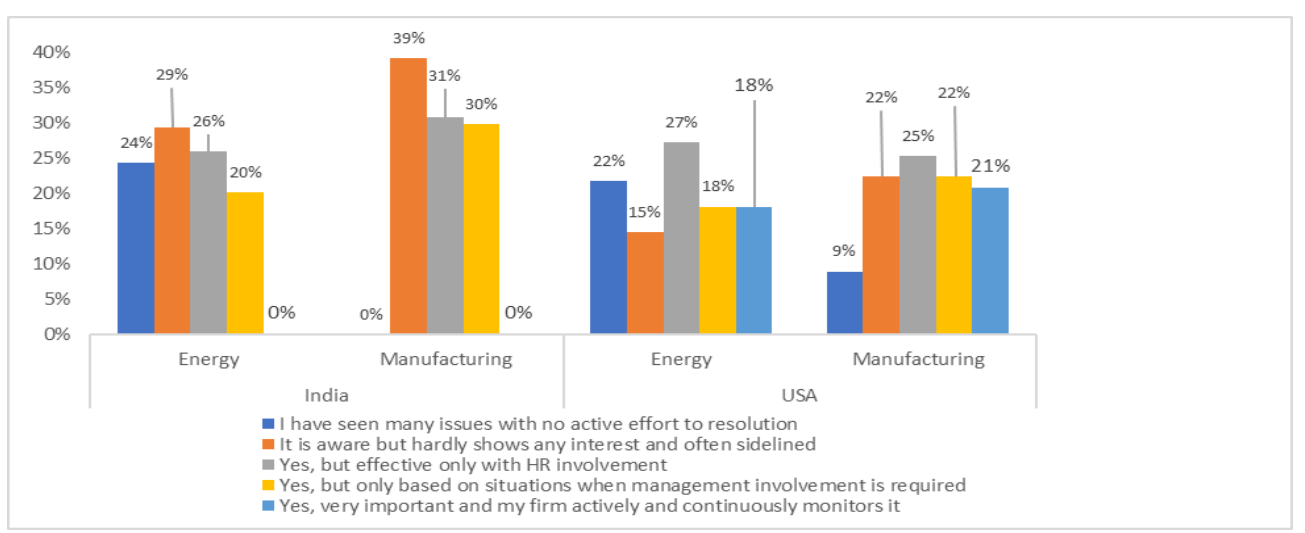

Figure 7: Employee discrimination.

H: Mani et al.(2015), Morais (2017) and Yawar \& Seuring (2017), in their studies, have specified that, measures like, establishing code of conduct with SCM partners, ensuring adherence and certifying to health \& safety standards, conducting awareness programs, audits and setting up monitoring systems, providing employee health insurance and benefits would help improve the health, safety and wellbeing of the employees at the supply chain organizations. Figure 13 and 17 represent other focused aspects that contribute to the HSE aspect of firms in general.

I: Mani et al. (2015). lists housing as an important social dimension, especially in manufacturing supply chains in emerging economies. According to Read et al. (2012), insufficient availability of affordable housing leads to many negative aftermaths in the society, which would in turn result in under development of communities, poor healthcare, increase in criminal activities and children missing out on education. Figure 17 represents sanitation which is a key factor influenced by this very social issue.

J: Non-profit Organizations and other human rights advocates often prompt consumer boycotts, in case of major human rights violations they come across (Zadek, 2005). Firms can reduce human rights violations by following international standards and practices, framing codes of conduct with their supply chain partners and auditing (Mani et al., 2015; Morais, 2017). Figure 2, 3, 4, 5, and 7 show response pertaining to child labor, employee rights, ethics, fairness and discrimination that are primary triggers for the boycott. Results show a higher possibility of boycott in developing regions and sectors, in comparison to 
the developed regions and sectors. However, boycott impacts are higher on developed sectors and regions that have sourcing strategies from their developing regions, purely due to more governing rules on exploitation. This gap can exist even within sectors of same geographies.

K: Yawar and Seuring (2017) found labor conditions to be the most discussed social dimension in the sustainability of supply chain organizations, and it helps in employee retention and positive stakeholder reputation. Figures 3 and 4 provide insights to the employee and their firms perspective on employee rights, while Figure 18 ascertains a work-life balance. Both aspects are tied in closely with labor conditions.

L: Local community development is a major indicator of social sustainability and companies should play an important role to invest and interact more with their social environment (Morais, 2017). The issue often flares up in political ballots and voting but is then forgotten until the next run. This issue is not limited to just emerging countries but extends to several developed regions of the world. Figure 8 provides a varied mix to the social issue. While arguably " Hardly practices any local community empowerment” and “ focus on its own Cash margins" may appear redundant to each other, it is striking to see than nearly $30 \%$ of every sector and geography saw profits over community as an underlying issue.

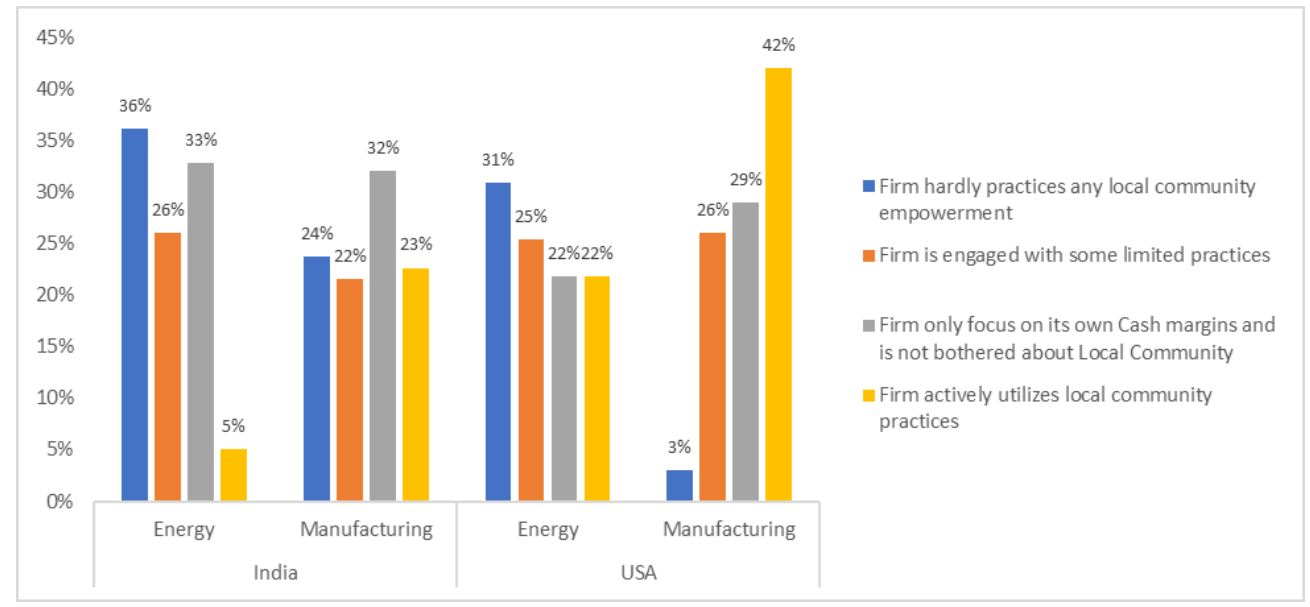

Figure 8: Community empowerment.

M: There's no set definition for minorities and it varies with geographies. Morais (2017) and Yawar \& Seuring (2017), in their studies on social issues, have underlined the benefits of minority inclusion in the supply chain improvement. Benefits of which include value creation, innovation and other geographic expansion based financial improvements. Figure 9 points distinctively no sector or geography claimed to have a very thoroughly embedded method to tackle this social issue. Figure 9 shows a varied perspective to the firm's approach with a relatively low confidence on commitment from firms. 




Figure 9: Minority development.

$\mathrm{N}$ : People with physical disability make the highest percentage of neglected population, also called "marginalized population". Other categories include those neglected by their governments and those living below the poverty line (Yawar and Seuring, 2017). As per World Health Organization (WHO), fifteen percent of the world population has some form of disability. Inclusion of this marginalized population through socially responsible activities would improve their plight, and in general, will benefit the company and the communities. Figure 10 provides a clear picture of more work needed in both sectors in India on the topic. Both sectors in the US show a strong positive response to embedded in corporate culture.



Figure 10: Marginalized Population exclusion.

O: United Nations refer to philanthropy as a prominent factor in developing sustainability, as it supports all other dimensions of social sustainability. From the papers reviewed in this systematic literature review, corporate volunteering, donations, NGO participation, philanthropic investment initiatives like trust funds towards various causes, help in philanthropy (Mani et al., 2016; Morais, 2017), and in turn provide ideas for more socially sustained supply chain models. Data from participants projected a very interesting find in figure 11, where US-Manufacturing and India-Energy show heavier weightage in having minimum to no involvement, while the US energy sector and Indian manufacturing show a higher philanthropic engagement. Authors believes the results are impacted by socio- 
political reasons. USA manufacturing is not as community knit as Indian manufacturing, largely comprising or mid-sized firms with little political or media liability. In sharp contrast US energy sector is influenced by various socio-political agenda unlike their Indian counterparts that are largely government owned or influenced.

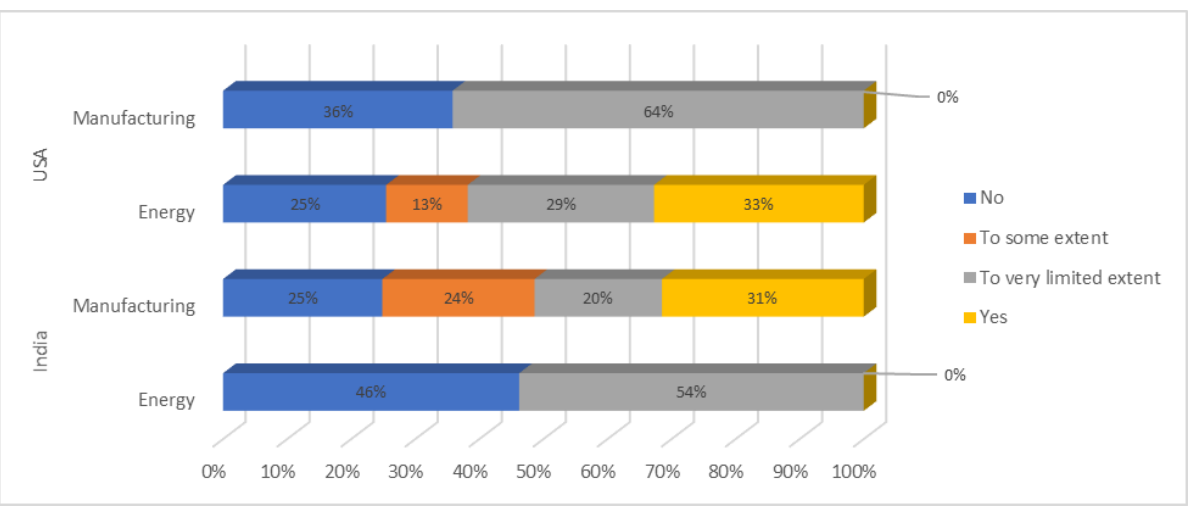

Figure 11: Philanthropic initiatives.

P: Hutchins and Sutherland (2008) and Ni et al. (2010) have mentioned population growth rate as a major social issue, especially in emerging economies. High unemployment rate, insufficient infrastructure facilities, increased crime rates are all studied to have a direct corelation to the effects of the population explosion. Figure 14 demonstrates the effect of firms addressing unemployment, and Figure 12 addresses the poverty both of which are systemic to population growth. Figure 15, on the contrary, ascertains the effects of unexpected events that can be of high concern to a large population area or to the remoteness of the location itself. All of these either bear or are impacted by population. Q: Poverty is a big social issue in emerging economies, especially with huge population. Sustainable supply chains can help alleviate this to a certain extent by providing skill development training and other CSR activities (Yawar and Seuring, 2017); and there needs to be management commitment to spread it throughout the supply chain network (Kortelainen, 2008). Figure 12 explains that given the population and \% of people below poverty line, the sentiments from the sectors in India undeniably ascertain firms cannot solve the social issue. In contrast where there is a sizeable difference to this in the USA, sectors lean more favorably to being able to help address the issue.

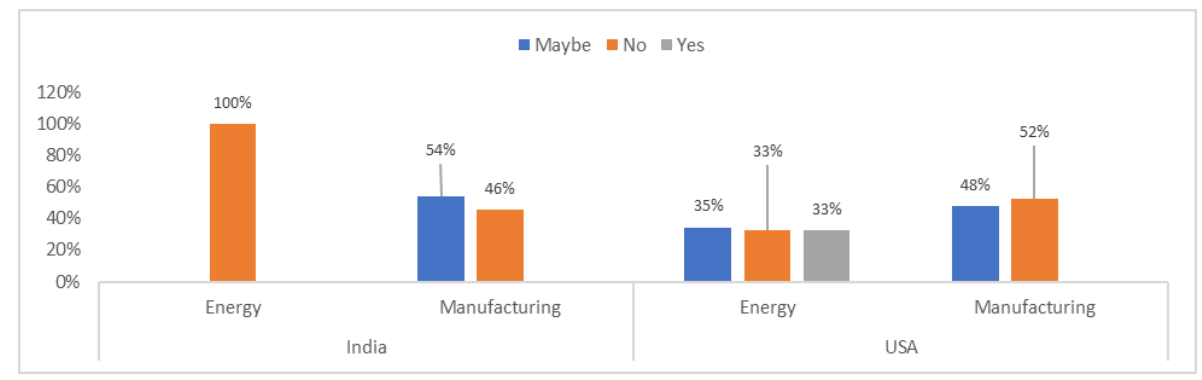

Figure 12: Poverty 
R: Consumers always demand transparency, and efforts to include social dimension, product responsibility, health and safety aspects about the commodity, through the display of product details via labelling and other communication methods, provide clarity. Customer service channels, vendor codes of conduct, safety standards are all various tools of product responsibility (Morais, 2017). Product responsibility is closely linked to fair trade and transparency along with ethics results of which are shown in Figure 5 and in Figure 6 respectively.

S: Sanitation problem can be mitigated by awareness programs, providing funding for or building sanitation facilities (Mani et al., 2016). While insight from NGO's like World Toilet Organization, Kindara, Afripads continue to make standing impacts, sanitization continues to be an aspect that needs large corporate help. A report by AC Neilsen and Plan India provides a deep insight into this very basic cycle represented as a "taboo". Figure 13 shows the employees perspective to the social issues. Note how a majority points to a resolution from the government or the community itself . This strong reflection of the employees reflects firms themselves and explains why few firms actively involved in this social issue.

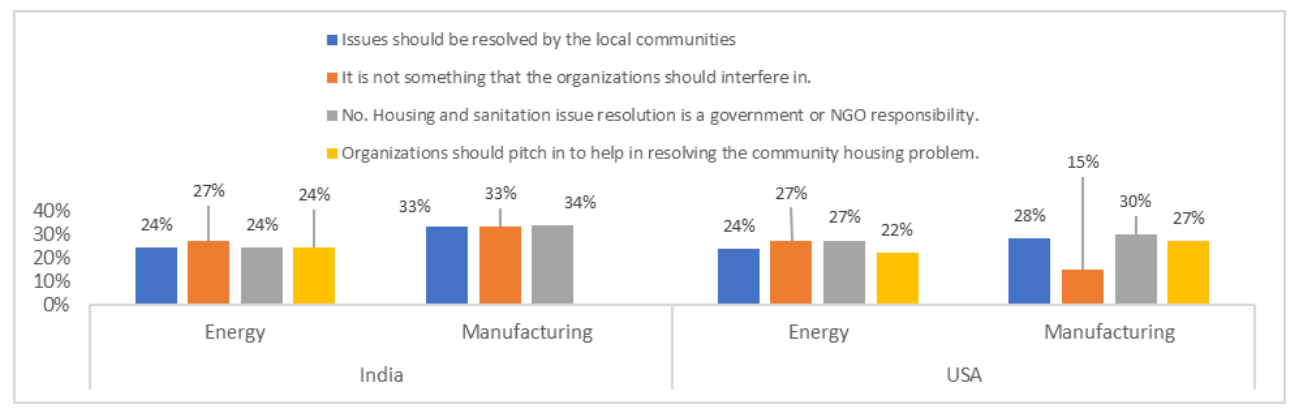

Figure 13: Housing and sanitation.

T: Poor labor practices, engagement and development of minority vendors have been found as a separate issue to labor conditions faced in the supply chain management (Klassen and Vereecke, 2012). Herein the reference is not to the one within the firm but in supply chain network. Such issues can be resolved by routine monitoring, assessment and auditing of the suppliers. IKEA's Iway is an example of a corporate endeavor to address such issues, however, not all supply chain models emphasize the aspect to the required levels.

U: Training of skills and sustainability awareness is vital for supplier development (Kumar and Rahman, 2015), and helps to improve their capacity, processes and performance (Klassen and Vereecke, 2012). Economic performance improvement occurs through training and knowledge sharing with the supply chain partners, since it helps in employee retention (Yawar and Seuring, 2017). Community development and income generation happens if firms invest time and money in vocational training programs (Mani et al., 2015). V: Mani et al. (2015), in their study on supply chain social sustainability, mention employment creation as an important social dimension, for which, firms can help by offering training programs for skill development and promoting more local hiring using the very reasons that cause unemployment. Figure 14 demonstrates that firms are not 
actively engaged in developing employment opportunities in communities. Of the two sectors, manufacturing shows a higher percentage of engagement. This could be for having skilled workers, that comprise of the larger workforce, availability during ramp up and ramp down times in comparison to degreed level qualification required in the other sector.

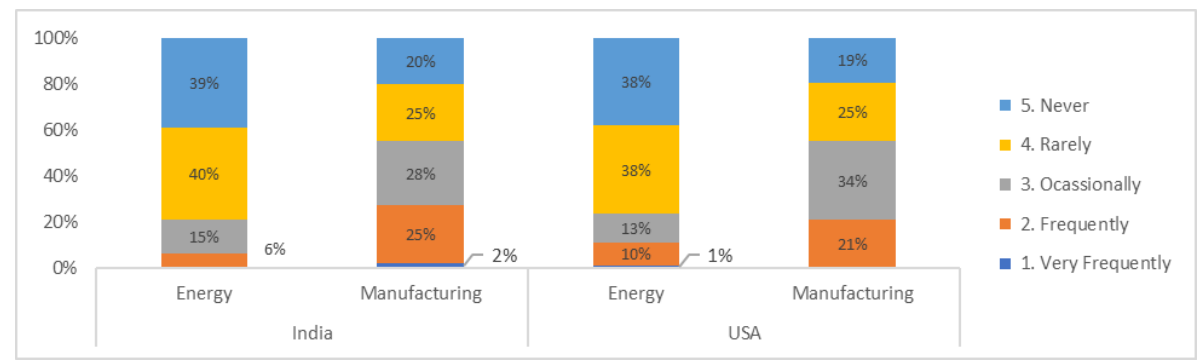

Figure 14: Unemployment around communities

W: Kleindorfer \& Saad (2005) and Klassen \& Vereecke (2012) have noted unexpected negative events like catastrophes, pandemics like COVID-19, natural disasters, etc. as a social issue, since it leads to financial and value loss, due to process failures and supply disruption. As seen in Figure 15, both sectors across geographies are either not much prepared or are prepared only to some /limited extent. The Energy sector in the US however scales near 50 percentage points and seems to be reasonably prepared in addressing the issues.

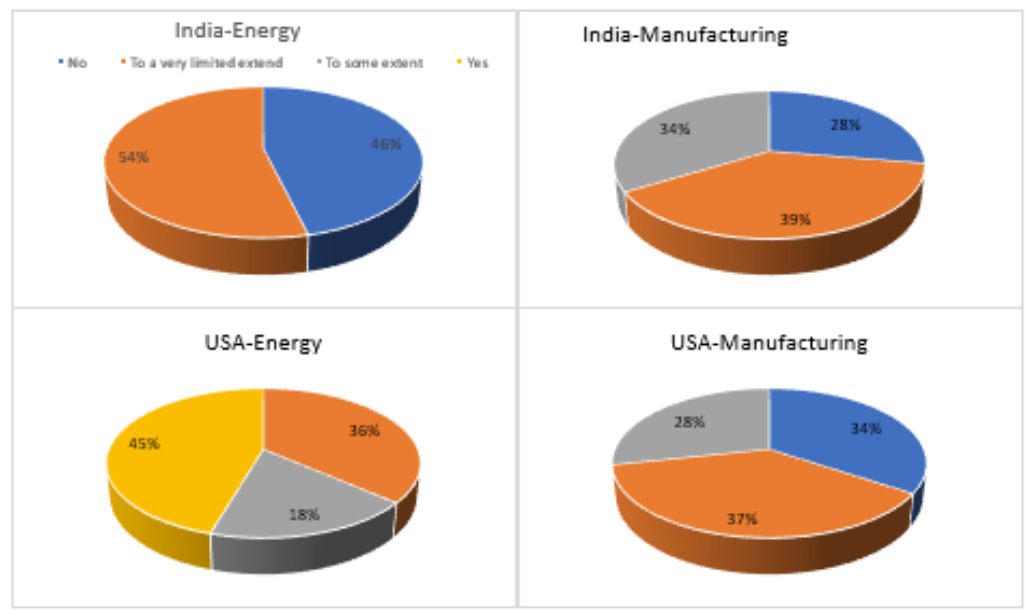

Figure 15: Unexpected negative events

X: Low and below market wages to the staff leads to decreased employee productivity, thereby resulting in supply chain performance deterioration (Yawar and Seuring, 2017). This issue can be resolved via long term settlement agreements and ensuring competitive, on-par-with-market and fair wages to the staff (Mani et al., 2015; Kumar and Rahman, 2015). In almost all cases results show that employees believe there is scope for firms to 
address wages and improve lifestyle, as seen in Figure 16. An interesting observation is that while US has a high degree of participants claiming a need for more importance, India seems to have a mix of spread on this topic. This adds complexity by the very fact that the average Indian worker is paid much less than an average worker in the US. Authors believes this is related to some extent on the average happiness index coupled with medical costs and lifestyle.

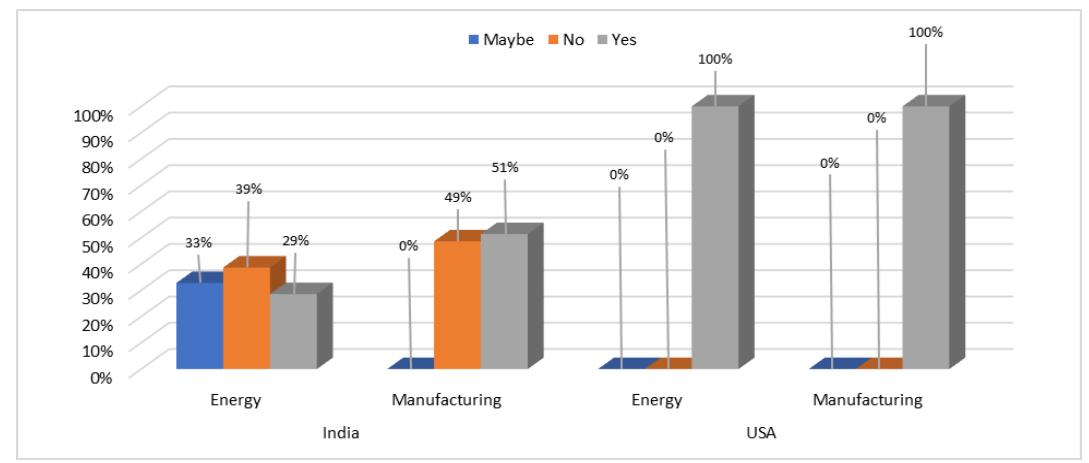

Figure 16: Wage or salary

Y: Women specific issues (Kumar and Rahman, 2015) include women's security at workplace and other exploitation possibilities (Yawar and Seuring, 2017), which the firms can mitigate by ensuring implementation of women-specific safety practices and policies at all the supply chain partner facilities. Organizations can enhance women's skills through vocational training, thereby making them employable and help in income generation where currently women are not employed and provide equal growth opportunities where representation is limited (Mani et al., 2015). Energy sectors in both the USA and in India seem to opinionate heavily on either not being sure of the firm's importance to the subject or in being able to address the issue when needed. Figure 17 further demonstrates that the manufacturing sectors on the other hand seem to have an even distribution across the choices on how their firms perceive the issue. A higher female representation in the manufacturing industry in comparison to the energy sector could be one reason for the results observed.



Figure 17: Women specific issues. 
Z: Work-life balance refers to the degree of prioritization of personal and career obligations of people, with enough relaxation and recreation time. Kumar and Rahman (2015), in their study have found work and life balance as a social issue affecting supply chains leading to diminished productivity. Figure 18 demonstrates a higher weightage effort required from firms to address the work life balance issue.

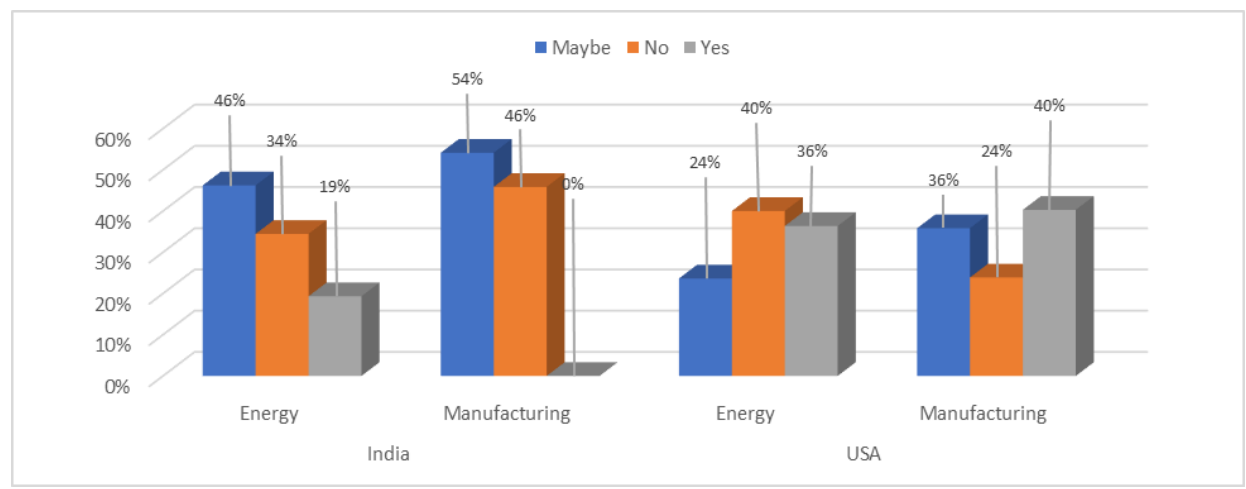

Figure 18: Work-life balance.

\section{Conclusion}

While the review of various papers enabled to capture the 26 social issues researched in the field, the questionnaire survey defined a perspective on how well firms are addressing these issues. As social sustainability is a relatively younger concept across geographies, there is a vast scope of improvement and research that can help mitigate these issues and lead firms to better social sustainability.

The results clarify that the Indian sectors still need to address child labor; with the current low $(30 \%)$ confidence on firms enabling mitigation of the issue. Further, employment discrimination is a key social issue that needs attention along with fairness to suppliers like that shown with customers in the region. Both sectors in India also need to focus on neglected population inclusion, like the US sectors, to achieve a substantial change.

Results also enable us to conclude that employee rights is a key social issue across geographies across the two sectors, and that a local community empowerment is largely clouded by firms focusing on their own margins which is severely detrimental to mitigation efforts. Such behavior often stems from a lack of ownership and commitment to social issues from the firms.

Further, across geographies, sectors are in absolute need of a continuous monitoring of gender bias to enable inefficiency elimination in addressing the issue. Similar enablers are essential to minority development, given no sector or geography is confident to claim practices addressing the issue are embedded in their corporate culture. enablers are key to address these systemic barriers. These enablers cannot however be generic as they depend on the geography, sector and women population in the sector. Also adding to this is complexities stemming from political and other socio/cultural factors. Manufacturing sectors across geographies were more receptive to firms addressing unemployment around communities, in comparison to the energy sector. Laws to enforce some community 
employment efforts would enable the energy sector to put more efforts and focus to address this.

An interesting and noteworthy social issue that gains a lot of attention is sanitation. Even though research strongly suggest a correlation between sanitation and supply chain inefficiencies, the sample results from the two sectors of energy and manufacturing largely considered this to be a topic that must be handled by local communities and governments rather than by firms themselves. Poverty reduction was also observed in similar light but with a higher positivity on firms influencing a change, in the US compared to that in India. It is evident that social issues on ethics policy and philanthropic activities need a much deeper dive and analysis.

Top social issues that require high focus across sectors and some simple mitigation methods are listed in table 3

Table 3: Simplified mitigation of social issues across sectors in geographies

\begin{tabular}{|c|c|c|c|}
\hline \multirow{2}{*}{$\begin{array}{l}\text { Sector } \\
\text { Energy }\end{array}$} & \multirow[b]{2}{*}{$\begin{array}{l}\text { Issues } \\
\text { requiring } \\
\text { high focus }\end{array}$} & \multicolumn{2}{|l|}{ Simplified Mitigation Approach } \\
\hline & & India & $U S A$ \\
\hline & $\mathrm{D} \& \mathrm{G}$ & $\begin{array}{l}\text { Inclusion targets at every } \\
\text { managerial level. }\end{array}$ & Monitoring \\
\hline & F & Ethical Guidelines & $\begin{array}{l}\text { Improved Collaboration and } \\
\text { Partnerships }\end{array}$ \\
\hline & $\mathrm{N}$ & Inclusion policies and standards & \\
\hline & $\mathrm{C}$ & Incentivized Labor unions & $\begin{array}{l}360 \text { Management, workforce } \\
\text { review }\end{array}$ \\
\hline & $\mathrm{M}$ & Regular monitoring and updates & $\begin{array}{l}\text { Regular monitoring and } \\
\text { updates }\end{array}$ \\
\hline Manufacturing & $\begin{array}{c}\text { Issues } \\
\text { requiring } \\
\text { high focus }\end{array}$ & India & $\boldsymbol{U S A}$ \\
\hline & A & $\begin{array}{l}\text { Corporate engagement and } \\
\text { penalties }\end{array}$ & \\
\hline & $D \& G$ & $\begin{array}{l}\text { Corporate commitment and } \\
\text { communication, followed by } \\
\text { published inclusion targets at } \\
\text { every employee level. }\end{array}$ & $\begin{array}{l}\text { Inclusion targets at every } \\
\text { managerial level. }\end{array}$ \\
\hline & $\mathrm{F}$ & Ethical Guidelines & $\begin{array}{l}\text { Improved Collaboration and } \\
\text { Partnerships }\end{array}$ \\
\hline & $\mathrm{N}$ & Inclusion policies and standards & Continuous monitoring \\
\hline & $\mathrm{C}$ & Incentivized Labor unions & Incentivized Labor unions \\
\hline & M & $\begin{array}{l}\text { Ethical Guidelines with training } \\
\text { that have a yearly expiry. } \\
\text { Inclusion of training in new } \\
\text { onboarding programs }\end{array}$ & $\begin{array}{l}\text { Ethical Guidelines with } \\
\text { training that have a yearly } \\
\text { expiry. Inclusion of training in } \\
\text { new onboarding programs }\end{array}$ \\
\hline
\end{tabular}

Future research should focus on the social sustainability practices specific to supply chain models on other specific industries and on how to measure their impacts in improving 
efficiencies. More work on social sustainability awareness is required to develop further concrete and meaningful enablers in the field.

\section{References}

Ageron, B., Gunasekaran, A., \& Spalanzani, A. (2012). Sustainable supply management: An empirical study. International Journal of Production Economics, 140(1), 168-182. doi:10.1016/j.ijpe.2011.04.007

Ansett, Sean. (2007). Mind the Gap: A Journey to Sustainable Supply Chains. Employee Responsibilities and Rights Journal. 19. 295-303. doi:10.1007/s10672-007-9055-x.

Ashby, Alison \& Leat, Mike \& Hudson Smith, Mel. (2012). Making connections: A review of supply chain management and sustainability literature. Supply Chain Management: An International Journal. 17. 497-516. doi: 10.1108/13598541211258573.

Babbie, E. (2010) The practice of social research. 12th Edition, Wadsworth, Belmont.

Björklund, Maria. (2010). Linking strategic logistics change to labor rights. Social Responsibility Journal. 6. 580-592. doi: 10.1108/17471111011083455.

Chase.(2007).PSRQuestionaireTipSheet. Harvard Retrieved from https://psr.iq.harvard.edu/files/psr/files /PSRQuestionnaireTipSheet_0.pdf

Closs, David \& Speier, Cheri \& Meacham, Nathan. (2011). Sustainability to Support End-to-End Value Chains: The Role of Supply Chain Management. Journal of the Academy of Marketing Science. 39. 101-116. doi: 10.1007/s11747-010-0207-4.

Higgins, M \& Ellis, N (2006) The Search for Justice in Supply Chain Management: A Levinasian Perspective, EGOS Bergen, June 2006

Hall, Jeremy \& Matos, Stelvia. (2010). Incorporating Impoverished Communities in Sustainable Supply Chains. International Journal of Physical Distribution \& Logistics Management. 40. 124-147. doi: 10.1108/09600031011020368.

Hutchins, Margot \& Sutherland, John. (2008). An Exploration of Measures of Social Sustainability and their Application to Supply Chain Decisions. Journal of Cleaner Production - J CLEAN PROD. 16. 16881698. doi: 10.1016/j.jclepro.2008.06.001.

Klassen, Robert \& Vereecke, Ann. (2012). Social issues in supply chains: Capabilities link responsibility, risk (opportunity), and performance. International Journal of Production Economics. 140. 103-115. doi: 10.1016/j.ijpe.2012.01.021.

Kleindorfer, Paul \& Saad, Germaine. (2009). Managing Disruption Risk in Supply Chains. Production and Operations Management. 14. 53 - 68. doi: 10.1111/j.1937-5956.2005.tb00009.x.

Kolk, Ans \& Tuldere, Rob. (2002). Child Labor and Multinational Conduct: A Comparison of International Business andStakeholder Codes. Journal of Business Ethics. 36. 291-301. doi: 10.1023/A:1014009313508.

Kortelainen, Ketty. (2008). Global Supply Chains and Social Requirements: Case Studies of Labour Condition Auditing in the People's Republic of China. Business Strategy and the Environment. 17. 431 - 443. doi: $10.1002 /$ bse. 634 .

Kumar, Divesh \& Rahman, Zillur. (2015). Sustainability adoption through buyer supplier relationship across supply chain: A literature review and conceptual framework. International Strategic Management Review.3. 110-127. doi: 10.1016/j.ism.2015.04.002.

Leire, Charlotte \& Mont, Oksana. (2009). The Implementation of Socially Responsible Purchasing. Corporate Social Responsibility and Environmental Management. 17. 27 - 39. doi: 10.1002/csr.198.

Mani, Venkatesh \& Agrawal, Rajat \& Sharma, Vinay. (2015). Supply Chain Social Sustainability: A Comparative Case Analysis in Indian Manufacturing Industries. Procedia - Social and Behavioral Sciences. 189. 234-251. doi: 10.1016/j.sbspro.2015.03.219.

Mani, Venkatesh \& Gunasekaran, Angappa \& Papadopoulos, Thanos \& Hazen, Benjamin \& Dubey, Rameshwar. (2016). Supply chain social sustainability for developing nations: Evidence from India. Resources, Conservation and Recycling. 111. 42-52. doi: 10.1016/j.resconrec.2016.04.003.

Markley, Melissa \& Davis, Lenita. (2007). Exploring Future Competitive Advantage Through Sustainable Supply Chains. International Journal of Physical Distribution \& Logistics Management. 37. 763-774. doi: 10.1108/09600030710840859. 
Matos, Stelvia \& Hall, Jeremy. (2007). Integrating Sustainable Development in the Supply Chain: The Case of Life Cycle Assessment in Oil and Gas and Agricultural Biotechnology. Journal of Operations Management. 25. 1083-1102. doi: 10.1016/j.jom.2007.01.013.

Morais, Dafne. (2017). Social sustainability in supply chains: A framework and a Latin America illustrative case. Journal of Operations and Supply Chain Management. 10. 32. doi: 10.12660/joscmv10n2p32-43

Nadvi, Khalid. (2008). Global Standards, Global Governance and the Organization of Global Value Chains. Journal of Economic Geography. 8. 323-343. doi: 10.1093/jeg/lbn003.

Ni, Debing \& Li, Kevin \& Tang, Xiaowo. (2010). Social responsibility allocation in two-echelon supply chains: Insights from wholesale price contracts. European Journal of Operational Research. 207. 1269-1279. doi: 10.1016/j.ejor.2010.06.026.

Olorunniwo, Festus \& Li, Xiaoming. (2010). Information Sharing and Collaboration Practices in Reverse Logistics. Supply Chain Management-an International Journal - SUPPLY CHAIN MANAG. 15. 454-462. doi: 10.1108/13598541011080437.

Palmer Morrel-Samuels. (2002). Getting the Truth into Workplace Surveys, The Magazine, Harvard Business Review. Retrieved from https://hbr.org/2002/02/getting-the-truth-into-workplace-surveys

Peters, Nils \& Hofstetter, Joerg S. \& Hoffmann, Volker. (2011). Institutional entrepreneurship capabilities for interorganizational sustainable supply chain strategies. International Journal of Logistics Management, The. 1. 52-86. doi: 10.1108/09574091111127552.

Pullman, Madeleine \& Maloni, Michael \& Carter, Craig. (2009). Food for Thought: Social Versus Environmental Sustainability Practices and Performance Outcomes. Journal of Supply Chain Management. 45. 38 - 54. doi: 10.1111/j.1745-493X.2009.03175.x.

Read, Dustin \& Tsvetkova, Alexandra. (2012). Housing and social issues: A cross disciplinary review of the existing literature. Journal of Real Estate Literature. 20. 3-35.

Roscigno,V. (2019). Discrimination, Sexual Harassment, and the Impact of Workplace Power. doi: $10.1177 / 2378023119853894$.

Seuring, Stefan \& Müller, Martin. (2008). Core Issues in Sustainable Supply Chain Management-A Delphi Study. Business Strategy and the Environment. 17. 455 - 466. doi: 10.1002/bse.607.

Shamon, H., \& Berning, C. C. (2020). Attention Check Items and Instructions in Online Surveys with Incentivized and Non-Incentivized Samples: Boon or Bane for Data Quality?. Survey Research Methods, 14(1), 55-77. https://doi.org/10.18148/srm/2020.v14i1.7374

Simões, M. (2014). Social key performance indicators - Assessment. in supply chains. Técnico Lisboa. June, pp. 1-10.

Smith, B. (2008). Developing sustainable food supply chains. Philosophical transactions of the Royal Society of London. Series B, Biological sciences. 363. 849-61. doi: 10.1098/rstb.2007.2187.

Singh, Vrinda.(2019). "Survey Response Bias: 3 Most Harmful Biases (ङ How To Avoid Them)”. Paperform article. Retrieved from https://paperform.co/blog/survey-response-bias

Yawar, Sadaat \& Seuring, Stefan. (2017). Management of Social Issues in Supply Chains: A Literature Review Exploring Social Issues, Actions and Performance Outcomes. Journal of Business Ethics. 141. doi: 10.1007/s10551-015-2719-9.

Zadek, Simon. (2005). The Path to Corporate Responsibility. Harvard business review. 82. 125-32, 150. doi: 10.1007/978-3-540-70818-6_13. 